\title{
Enhanced Osseointegration of Porous Titanium Scaffold Implanted with Preload: An Experiment Study in Rabbits
}

\author{
Osteointegración Mejorada de Malla de Titanio Poroso Implantada \\ con Precarga: Un Estudio Experimental en Conejos
}

Linwei Lyu ${ }^{1,2}$; Ye Jing ${ }^{1,2}$; Jikun Wang ${ }^{3} \&$ Chunqiu Zhang ${ }^{1,2}$

LYU, L.; JING, Y.; WANG, J. \& ZHANG, C. Enhanced osseointegration of porous titanium scaffold implanted with preload: an experiment study in rabbits. Int. J. Morphol., 38(4):909-913, 2020.

SUMMARY: Porous titanium alloy scaffold was widely used in treating bone defect caused by traumatic injury and osteomyelitis, which was incapable of self-healing. The implantation of scaffold produced stress shielding thereby forming osteolysis. The objective of this study was to analysis trabecular morphological features of osseointegrated bone. 14 New Zealand rabbits were divided into two groups, surgery group and healthy control group. 7 rabbits in surgery group were selected to perform 3D printed porous titanium alloy scaffold implantation surgery with preload at the defect of femoral condyle for osseointegration. The other 7 rabbits in control group were feed free. After 90 days healing, femoral condyles were extracted to perform micro-CT scanning with hydroxyapatite calibration phantom. Mean bone mineral density (BMD), bone volume fraction (BV/TV), BS/TV (bone surface area ratio), Tb.Th (thickness of trabeculae), Tb.N (number of trabeculae), Tb.Sp (trabecular separation) and DA (degree of anisotropy) were calculated from micro-CT images. The results revealed that osseointegration inside and at the surface of scaffolds worked well from grey values of micro-CT images. After 12 weeks healing, mean bone mineral densities (BMD) in surgery group and healthy control group were calculated as $800 \pm 20 \mathrm{mg} / \mathrm{cm} 3$ and $980 \pm 90 \mathrm{mg} / \mathrm{cm} 3$, respectively. This revealed that the strength of trabeculae in surgery group might lower than that in the healthy group. Trabecular morphological parameters test showed that trabecular morphological parameters at the surface of scaffolds in the surgery group deteriorated significantly. It was found from micro-CT images that ingrowth bone was filled with pores of scaffold. Overall, the effect of osseointegration was promoted through the change of mechanical micro-environment in the scaffold region. Overall, preload could improve osseointegration effect in the long-term after surgery. However, the trabecular morphology in the surgery group was deteriorated, which might bring secondary fracture risk again.

KEYWORDS: Osseointegration; 3D printed porous titanium alloy scaffold; preload; micro-CT; rabbit femoral condyle defect.

\section{INTRODUCTION}

Osseointegration was a research hotspot in treating bone defect, trauma, infection and bone tumor in the clinical and research field of orthopedics (Wang et al., 2017a). According to WHO report in 2015, about 75 million people suffered from trauma, in which $10 \%-30 \%$ victims were unable to walk (Paka \& Pokrowiecki, 2018). Bone autograft was considered as a golden rule in bone defect repair (Dreifke et al., 2015). However, in most cases, it was impossible to acquire patient bone autograft during the treatment (Winkler el al., 2018). Nowadays, porous titanium alloy scaffold was widely used in clinical with its advantages of good mechanical properties, biocompatibility, and stable chemical composition (Torres-Sanchez et al., 2017).
Osseointegration, defined as bone ingrowth without interposed soft tissue, was found at bone to titanium screw implant contact surface (Carlsson et al., 1986). Osseointegration was found through microscopy after 3 months surgery. In recent years, 3D printing technology of titanium alloys had been developed and matured. With the introduction of 3D printing technology in prosthesis, the manufacture of porous titanium alloy scaffold became possible. In vivo studies of rabbit scaffold implantation, significant osseointegration and bone ingrowth ability of porous titanium alloy scaffold were found clearly through micro-CT images at four weeks after surgery (Chen et al., 2017). Meanwhile, integration of ingrowth tissue with

\footnotetext{
${ }^{1}$ Tianjin Key laboratory for Advanced Mechatronic System Design and Intelligent Control, Tianjin University of Technology, China.

${ }^{2}$ National Demonstration Center for Experimental Mechanical and Electrical Engineering Education (Tianjin University of Technology), China.

${ }^{3}$ Institute of Automatic Control and Robotics, Faculty of Mechatronics, Warsaw University of Technology; Poland.
} 
scaffold could maintain good mechanical micro-environment and biocompatibility obviously (Wang et al., 2016).

It was found from in vitro and in vivo experiments that $3 \mathrm{D}$ printed porous titanium alloy scaffold could promote the effect of bone in-growth in the short-term after surgery. Osseointegration period could be shrunk and through structural optimization and surface modification before surgery (Salou et al., 2015; Srivasa et al., 2017; Ilea et al., 2019). In general, 3D printed scaffolds with high porosities and low stiffness were benefit for bone ingrowth compared with traditional implant (Wang et al., 2016). The porous scaffold fabricated with approximate diameter of $500 \mu \mathrm{m}$ and porosity of $58 \%$ by selective laser melting method showed significant bone in-growth as well as on-growth in rabbit femoral condyles after four weeks to eight weeks (Srivasa $e t$ al.). The effect of osseointegration was further improved after surface modification. The pores of implant were completely filled with bone within eight weeks in rabbit femur. The implant with anodized titanium dioxide nanotubes surface presented higher but not significant bone-to-implant ratio and bone surface area at the distance of $0.5 \mathrm{~mm}$ than acid-etched surface or machined surface (Salou et al.). The porous scaffold with mesh size of 800 um and coated by nano-hydroxyapatite promoted the new bone formation and improved the osseointegration process best at the defect region when compared with uncoated scaffolds (Ilea et al.).

The role of mechanical stimulation was increasingly recognized in the pathogenesis of peri-prosthetic osteolysis (Wang et al., 2017b). There were no significant differences on osseointegration effect between loading group and unloading group in the early time of postoperation (Reitmaier et al., 2018). In vivo mechanical stimulation could promote bone ingrowth into metallic scaffold to enhance long-term fixation after surgery (Willie et al., 2010). Implantation group coupled with the mechanical stimulation exhibited higher healing quality in contrast to the corresponding unloaded group during 4 weeks and 8 weeks (Zhang et al., 2018). Bone-to-implant surface area in loading group was about $10 \%$ higher than unloading group at week 6 , and more than $30 \%$ at week 26 (Luan et al., 2019).

Limited literatures were available on mechanical properties of ingrowth bone tissue. Pull-out test could reflect trabecular mechanical properties of ingrowth bone tissue at the surface of oral implant (Ilea et al.). The Young's modulus of titanium alloy scaffold was significantly higher than bone tissue around. The stress shielding produced by scaffold broke original mechanical micro-environment resulting in abnormal bone remodeling In-growth bone tissue. Therefore, the mechanical properties of ingrowth bone tissue must be influenced.
The objective of this study is to compare trabecular morphological features after 90 days osseointegration in defect bone tissues with healthy trabecular tissues. All bone tissues were test using micro-CT after 90 days osseointegration. Trabecular morphological features in two groups were measured and compared at defect repair area. The change trends of trabecular morphological features were explored on ingrowth trabeculae long-term after surgery to provide applicable values for the improving mechanical micro-environment in clinical and bone tissue engineering research.

\section{MATERIAL AND METHOD}

Fourteen New Zealand rabbit with 2.5 months old and average weight of $2.5 \mathrm{~kg}$ were divided into two groups, including surgery group ( 7 rabbit) healthy control group ( 7 rabbit). 7 porous titanium alloy scaffolds were fabricated by $3 \mathrm{D}$ printer with the diameter of $2 \mathrm{~mm}$, the height of $5 \mathrm{~mm}$, porosity of $70 \%$, pore diameter of $0.65 \mathrm{~mm}$ and wire diameter of $0.32 \mathrm{~mm}$.

Rabbits in surgery group were anesthetized with 10 $\%$ w/v chloral hydrate solution. Intraperitoneal dose was calculated with $3.5 \mathrm{ml}$ per kilogram weight. Regions around right condyles of femur were shaved clearly and skins were exposed. Limbs of rabbits were extended fixed on the operation table. $2 \mathrm{ml}$ lidocaine hydrochloride with concentration of $0.02 \mathrm{~g} / \mathrm{ml}$ was injected subcutaneously at knee joint for local anesthesia after skin disinfection with iodine. An incision of 4-5 cm was made at lateral knee using scalpel to exposed femoral condyle. A Small amount of lidocaine hydrochloride would be sprayed while waking up from anesthesia. Drilling location was set at the interosseous eminence center of right femoral condyle of rabbit. Drilling dimension was with the diameter of $1.9 \mathrm{~mm}$ and depth of $5 \mathrm{~mm}$. A sterilized 3D printed porous titanium alloy scaffold was implanted into drilling hole with preload produced by interference assembly. The implantation process was shown in Figure 1. The incision was sutured and disinfected with iodide. After waking up, rabbits were injected with enrofloxacin into the muscle of the operative leg with a dose of $0.2 \mathrm{ml} / \mathrm{kg}$ for three consecutive days. All rabbits were sacrificed at 90 days after surgery. The right femurs were extracted and frozen in $-40{ }^{\circ} \mathrm{C}$ freezer.

All femurs in two groups were performed micro-CT scanning. Micro-CT scanning parameters were pixel size 32 um, thickness 32 um, ROI 1500*1500 px, 1400 slices, voltage $190 \mathrm{kV}$, current $130 \mathrm{uA}$. All micro-CT images were imported into VG Studio MAX software to calculate 

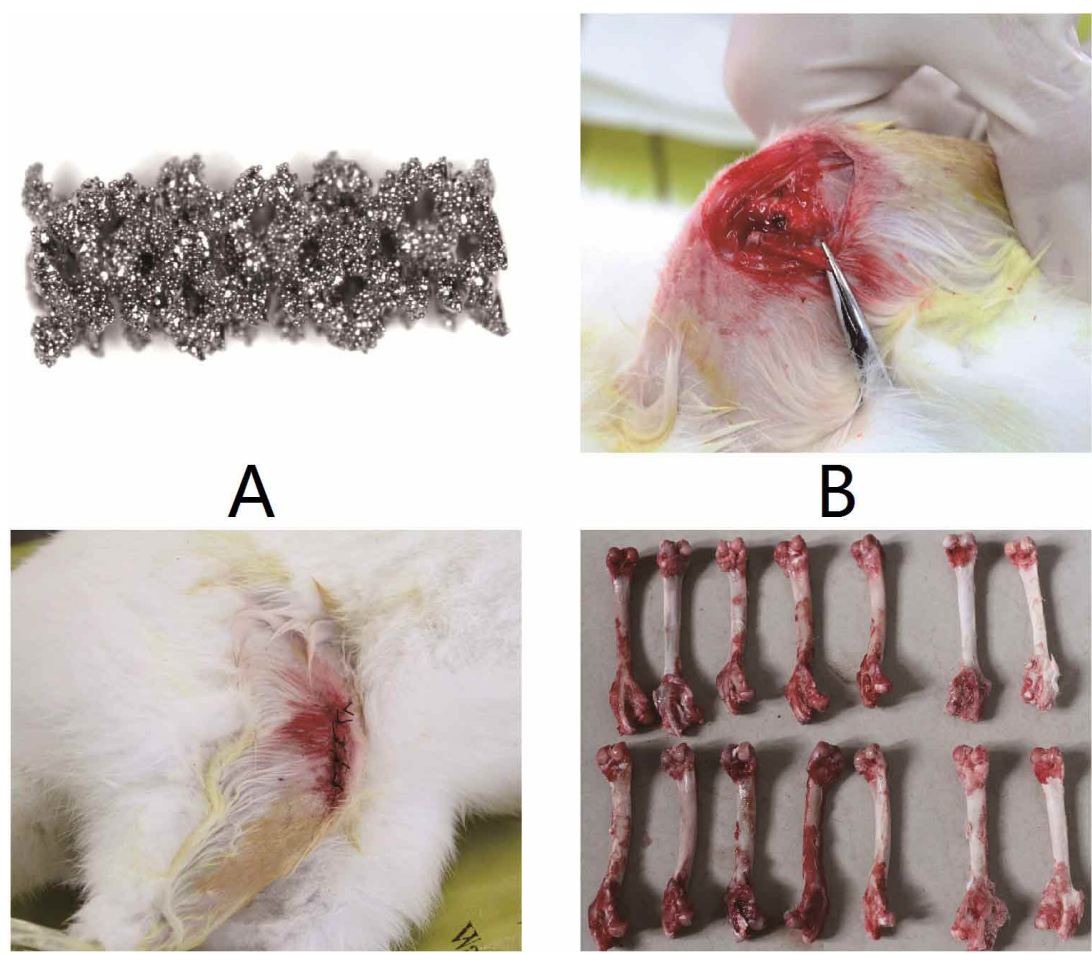

Fig. 1. Surgery process of scaffold implantation of a rabbit. A. 3D printed porous titanium scaffold. B. Surgery process of implantation. C. Stitching process after surgery. D. Right femurs from rabbits after 90 days osseointegration.

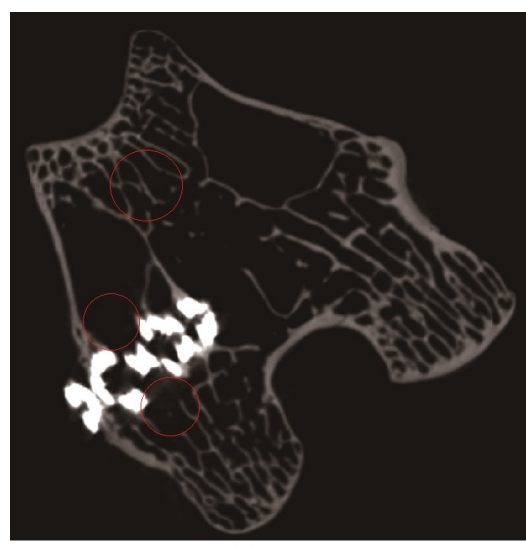

A

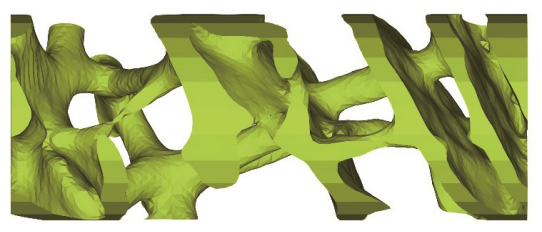

C

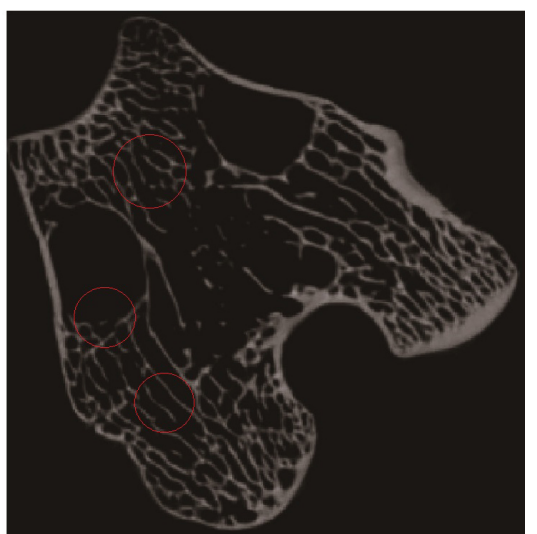

B
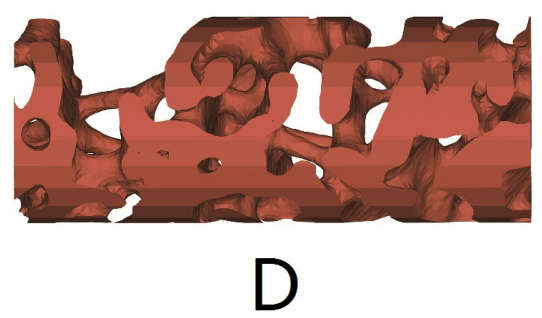

Fig. 2. Typical trabecular morphology comparison of surgery group and healthy control group. A. and B. Micro-CT images of femoral condyles from surgery group and healthy control group, respectively. C and D. 3D reconstruction models in the area of femoral condyles from surgery group and healthy control group, respectively. trabecular morphological parameters at the region of scaffolds, including BV/TV (bone volume fraction), BS/TV (bone surface area ratio ), Tb.Th (thickness of trabeculae), Tb.N (number of trabeculae), Tb.Sp(trabecular separation), DA (degree of anisotropy), BMD (bone mineral density).

All trabecular morphological parameters and bone mineral density data were expressed as an average \pm standard deviation. Independent-sample $\mathrm{T}$ tests were performed on each trabecular morphological parameter and BMD with significance level of $95 \%$. Significant difference value $P$ was considered of less than 0.05. All data were statistically analyzed and plotted in software SPSS 17.0.

\section{RESULTS}

Statistical analyses of trabecular morphological parameters revealed that there were significant differences between surgery group and healthy control group, which was shown in Table I as mean \pm standard deviation. BV/TV, Tb.Th and $\mathrm{Tb} . \mathrm{N}$ in surgery group were significantly lower than that in healthy control group. $\mathrm{BS} / \mathrm{BV}$ and $\mathrm{Tb} . \mathrm{Sp}$ in surgery group were significantly higher than that in healthy control group. There were no significant differences in DA between surgery group and healthy control group.

Typical micro-CT images and 3D reconstruction models in surgery group and healthy control group were shown in Figure 2. Significant differences of trabecular separation (Tb.Sp) were found in Figures $2 \mathrm{a}$ and $2 \mathrm{~b}$ with the red circle markers. Three-dimensional reconstructions were performed on the micro-CT images. It was shown from three-dimensional models in Figures $2 \mathrm{c}$ and $2 \mathrm{~d}$ that trabecular thickness (Tb.N) at the surface of scaffold in the surgery group was significant lower than that in healthy control group. 
Table I. Trabecular morphological parameters of rabbit femoral condyle.

\begin{tabular}{ccccccc}
\hline Groups & BV/TV & BS/BV & Tb.Th & Tb.N & Tb.Sp & DA \\
\hline Group A & $0.34 \pm 0.06$ & $11.61 \pm 2.27$ & $0.18 \pm 0.05$ & $0.77 \pm 0.21$ & $1.19 \pm 0.35$ & $0.44 \pm 0.10$ \\
Group B & $0.47 \pm 0.05$ & $7.15 \pm 1.82$ & $0.29 \pm 0.06$ & $1.65 \pm 0.27$ & $0.33 \pm 0.05$ & $0.36 \pm 0.10$ \\
Difference test & 0.000 & 0.006 & 0.008 & 0.000 & 0.002 & 0.224 \\
\hline
\end{tabular}

$\mathrm{P}<0.05$

\section{DISCUSSION}

This study focused on trabecular morphological features of osseointegrated bone tissues in the areas of porous titanium scaffolds. Rabbit femoral condyle defect model was established to perform osseointegration experiments. Bone defects, which caused by traumatic injury and osteomyelitis, were incapable of self-healing (McArthur et al., 2019). Porous scaffolds were widely used in treating trabecular bone defect to promoting cell proliferation, cell differentiation and bone ingrowth (Luan et al.). In our study, preload was exerted on the surface of scaffold using interference assembly with the interference of $0.1 \mathrm{~mm}$. In the previous studies, it was found that scaffolds with porosity of $60-70 \%$ and pore diameter of $100-400 \mu \mathrm{m}$ could fit mechanical properties of trabeculae better and were more suitable for osseointegration (Liang et al., 2019). Our results of rabbit osseointegration experiments revealed that porous scaffolds with porosity of $70 \%$ and pore diameter of $650 \mu \mathrm{m}$ promoted bone ingrowth effectively after 12 weeks healing.

Although scaffold had good osseointegration ability and osteogenic induction ability, osteolysis were still found from $20 \%$ revision surgeries (McArthur et al.). The main reasons for osteolysis were stress shielding caused by scaffold. In our study, the introduction of scaffold could still bring stress shielding, which could lead to osteolysis and high secondary fracture risk in the long-term after surgery. The statistical results showed that the significant reduced parameters were bone volume fraction (BV/TV), trabecular thickness (Tb.Th), number of trabeculae (Tb.N), and the significant increased parameters were trabecular surface ratio $(\mathrm{BS} / \mathrm{BV})$, trabecular separation (Tb.Sp) compared with healthy control group. These parameters all showed that the trabeculae deterioration trend at the surface of scaffolds. Peng et al. (2016) used commercial implants with resorbable blasting media treated surfaces to perform osseointegration on New Zealand rabbits. It was shown that bone volume fraction (BV/TV) was about $38 \%$ (Peng et al.). This result was basically consistent with our data in surgery group, and less than healthy control group. Therefore, it could be concluded that both preload and surface modification could promote osseointegration effect. The better effect of osseointegration would be obtained if these two methods were combined together. Li et al. investigated the enhanced osseointegration of the scaffolds coated with graphene (Li et al., 2018). The BV/TV in the graphene coated group was $33.548 \pm 2.678 \%$ and the BV/TV in the uncoated group was $24.911 \pm 2.898 \%$ at 12 weeks. These results were all lower than our surgery group with preload. Therefore, mechanical micro-environment was an important factor in promoting bone remodeling process in the mid-long-term surgery.

Bone mineral density is a mainly noninvasive test to analyze bone strength. Micro-CT HA phantom was scanned with the same scanning parameters as bone micro-CT images to calibrate bone mineral density of rabbit femoral condyle. In our study, after 12 weeks healing, mean bone mineral densities in healthy group and surgery group were calculated as $980 \pm 90 \mathrm{mg} / \mathrm{cm}^{3}$ and $800 \pm 20 \mathrm{mg} / \mathrm{cm}^{3}$, respectively. Although the scaffold was filled with ingrowth bone tissue at week 12, trabeculae within the range of stress shielding was not as strong as healthy control group. Secondary fracture risk might occur in the long-term after surgery. Surface modification had already induced osteoblast differentiation in the early postoperative period. However, in the long-term after surgery, mechanical micro-environment was necessary for bone remodeling.

\section{ACKNOWLEDGEMENTS}

This work was partly funded by National Natural Science foundation of China (No. 11702191, 11702190), China Postdoctoral Science Foundation (No. 2018M631751) and Tianjin Foundation (No. 18YFZCSY00890, 18ZXSGSY00010).

LYU, L.; JING, Y.; WANG, J. \& ZHANG, C. Osteointegración mejorada de andamio de titanio poroso implantado con precarga: un estudio experimental en conejos. Int. J. Morphol., 38(4):909-913, 2020.

RESUMEN: La malla de aleación de titanio poroso se usó ampliamente en el tratamiento de defectos óseos causados por lesiones traumáticas y osteomielitis. El implante de la malla generó una protección contra el estrés, formando así osteolisis. El objetivo de este estudio fue analizar las características morfológicas trabeculares del hueso osteointegrado. Se dividieron 14 conejos (Neozelandeses) en dos grupos, grupo cirugía y grupo control sa- 
ludable. Se seleccionaron 7 conejos en el grupo de cirugía para realizar una implantación de mallas de aleación de titanio poroso, impresas en 3D con precarga en el defecto del cóndilo femoral para la osteointegración. Los 7 conejos restantes del grupo control se mantuvieron sin alimentación. Después de 90 días de curación, se extrajeron los cóndilos femorales para realizar una exploración por micro-CT con un espectro de calibración de hidroxiapatita. Se calcularon a partir de imágenes de micro-CTDensidad mineral ósea media (DMO), fracción de volumen óseo (BV / TV), BS / TV (relación de área de superficie ósea), Tb.Th (espesor de trabéculas), Tb.N (número de trabéculas), Tb.Sp (trabecular separación) y DA (grado de anisotropía). Los resultados revelaron que la osteointegración dentro y en la superficie de los andamios funcionó bien a partir de los valores grises de las imágenes de micro-CT. Después de 12 semanas de curación, las densidades medias de minerales óseos (DMO) en el grupo cirugía y en el grupo control sano se calcularon como $800 \pm 20 \mathrm{mg} / \mathrm{cm}^{3}$ y $980 \pm 90 \mathrm{mg} / \mathrm{cm}^{3}$, respectivamente. Esto reveló que la fuerza de las trabéculas en el grupo de cirugía podría ser menor que la del grupo sano. La prueba de parámetros morfológicos trabeculares mostró que en el grupo de cirugía, la superficie de las mallas, se deterioraron significativamente. Se descubrió a partir de imágenes de microCT que el hueso en crecimiento estaba lleno de poros de andamio. En general, el efecto de la osteointegración se promovió mediante el cambio del microambiente mecánico en la región de la malla. En general, la precarga podría mejorar el efecto de osteointegración a largo plazo después de la cirugía. Sin embargo, la morfología trabecular en el grupo de cirugía se deterioró, lo que podría traer un nuevo riesgo de fractura secundaria.

PALABRAS CLAVE: Osteointegración; Mallas de aleación de titanio poroso impreso en 3D; precarga micro-CT; Defecto del cóndilo femoral en conejo.

\section{REFERENCES}

Carlsson, L.; Röstlund, T.; Albrektsson, B.; Albrektsson, T. \& Brånemark, P. I. Osseointegration of titanium implants. Acta Orthop. Scand., 57(4):2859, 1986.

Chen, Y.; Frith, J. E.; Dehghan-Manshadi, A.; Attar, H.; Kent, D.; Soro, N. D. M.; Bermingham, M. J. \& Dargusch, M. S. Mechanical properties and biocompatibility of porous titanium scaffolds for bone tissue engineering. J. Mech. Behav. Biomed. Mater., 75:169-74, 2017.

Dreifke, M. B.; Jayasuriya, A. A. \& Jayasuriya, A. C. Current wound healing procedures and potential care. Mater. Sci. Eng. C Mater. Biol. Appl., 48:651-62, 2015.

Ilea, A.; Vrabie, O. G.; Baban, A. M.; Miclus, V.; Ruxanda, F.; Sárközi, M.; Barbu-Tudoran, L.; Mager, V.; Berce, C.; Boca, B. A.; et al. Osseointegration of titanium scaffolds manufactured by selective laser melting in rabbit femur defect model. J. Mater. Sci. Mater. Med., 30(2):26, 2019.

Li, K.; Wang, C.; Yan, J.; Zhang, Q.; Dang, B.; Wang, Z.; Yao, Y.; Lin, K.; Guo, Z.; Bi, L.; et al. Evaluation of the osteogenesis and osseointegration of titanium alloys coated with graphene: an in vivo study. Sci. Rep., $8(1): 1843,2018$.

Liang, H.; Yang, Y.; Xie, D.; Li, L.; Mao, N.; Wang, C.; Tian, Z.; Jiang, Q. \& Shen, L. Trabecular-like Ti-6Al-4V scaffolds for orthopedic: fabrication by selective laser melting and in vitro biocompatibility. J. Mater. Sci. Technol., 35(7):1284-97, 2019.
Luan, H. Q.; Wang, L. T.; Ren, W. Y.; Chu, Z. W.; Huang, Y. F.; Lu, C. L. \& Fan, Y. B. The effect of pore size and porosity of Ti6Al4V scaffolds on MC3T3-E1 cells and tissue in rabbits. Sci. China Technol. Sci., 62:11608, 2019.

McArthur, B. A.; Scully, R.; Patrick Ross, F.; Bostrom, M. P. G. \& Falghren, A. Mechanically induced periprosthetic osteolysis: a systematic review. HSS J., 15(3):286-96, 2019.

Paka, K. \& Pokrowiecki, R. Porous titanium implants: a review. Adv. Eng. Mater, 20(5):1700648, 2018.

Peng, W.; Xu, L.; You, J.; Fang, L. \& Zhang, Q. Selective laser melting of titanium alloy enables osseointegration of porous multi-rooted implants in a rabbit model. Biomed. Eng. Online, 15(1):85, 2016.

Reitmaier, S.; Kovtun, A.; Schuelke, J.; Kanter, B.; Lemm, M.; Hoess, A.; Heinemann, S.; Nies, B. \& Ignatius, A. Strontium(II) and mechanical loading additively augment bone formation in calcium phosphate scaffolds. J. Orthop. Res., 36(1):106-17, 2018.

Salou, L.; Hoornaert, A.; Louarn, G. \& Layrolle, P. Enhanced osseointegration of titanium implants with nanostructured surfaces: an experimental study in rabbits. Acta Biomater, 11:494-502, 2015.

Srivas, P. K.; Kapat, K.; Dadhich, P.; Pal, P.; Dutta, J.; Datta, P. \& Dharaa, S. Osseointegration assessment of extrusion printed Ti6Al4V scaffold towards accelerated skeletal defect healing via tissue in-growth. Bioprinting, 6:8-17, 2017.

Torres-Sanchez, C.; Al Mushref, F. R. A.; Norrito, M.; Yendall, K.; Liu, Y. \& Conway, P. P. Torres-Sanchez, F.R.A. Al Mushref, M. Norrito, K. Yendall, Y. Liu, P.P. Conway. The effect of pore size and porosity on mechanical properties and biological response of porous titanium scaffolds. Mater. Sci. Eng. C Mater. Biol. Appl., 77:219-28, 2017.

Wang, G.; Roohani-Esfahani, S. I.; Zhang, W.; Lv, K.; Yang, G.; Ding, X.; Zou, D.; Cui, D.; Zreiqat, H. \& Jiang, X. Effects of Sr-HT-Gahnite on osteogenesis and angiogenesis by adipose derived stem cells for criticalsized calvarial defect repair. Sci. Rep., 7:41135, 2017a.

Wang, X.; Xu, S.; Zhou, S.; Xu, W.; Leary, M.; Choong, P.; Qian, M.; Brandt, M. \& Xie Y. M. Topological design and additive manufacturing of porous metals for bone scaffolds and orthopaedic implants: A review. Biomaterials, 83:127-41, 2016.

Wang, Z.; Wang, C.; Li, C.; Qin, Y.; Zhong, L.; Chen, B.; Li, Z.; Liu, H.; Chang, F. \& Wang, J. Analysis of factors influencing bone ingrowth into three-dimensional printed porous metal scaffolds: A review. J. Alloys Compd., 717:271-85, 2017b.

Willie, B. M.; Yang, X.; Kelly, N. H.; Han, J.; Nair, T.; Wright, T. M.; van der Meulen, M. C. \& Bostrom, M. P. Cancellous bone osseointegration is enhanced by in vivo loading. Tissue Eng. Part C Methods, 16(6):1399406, 2010.

Winkler, T.; Sass, F. A.; Duda, G. N. \& Schmidt-Bleek, K. A review of biomaterials in bone defect healing, remaining shortcomings and future opportunities for bone tissue engineering: The unsolved challenge. Bone Joint Res., 7(3):232-43, 2018.

Zhang, Y.; Chen, Y.; Kou, H.; Yang, P.; Wang, Y. \& Lu, T. Enhanced bone healing in porous Ti implanted rabbit combining bioactive modification and mechanical stimulation. J. Mech. Behav. Biomed. Mater, 86:33644, 2018.

\section{Corresponding author: \\ Chunqiu Zhang}

Tianjin Key laboratory for Advanced Mechatronic

System Design and Intelligent Control

Tianjin University of Technology

No. 391 Binshui Xidao

Xiqing District

Tianjin - CHINA

Received: 07-02-2020

Accepted: $10-03-2020$

\section{E-mail: zhang_chunqiu@126.com Ivlw@tjut.edu.cn}

